\title{
Phylogenetic Study of Acacia Species Using the Molecular Marker
}

\author{
Abdullah Alaklabi \\ Department of Biology, College of Science and Arts, Al-Baha University, Baljurashi, Saudi Arabia \\ Email: alaklabia@yahoo.com
}

Received 26 October 2015; accepted 8 December 2015; published 11 December 2015

Copyright ( 2015 by author and Scientific Research Publishing Inc.

This work is licensed under the Creative Commons Attribution International License (CC BY).

http://creativecommons.org/licenses/by/4.0/

c) (i) Open Access

\begin{abstract}
Acacia species are found at various arid and semiarid regions. Among the tree genera of family, Fabaceae, Acacia contains the highest number of species. We have collected different species of Acacia from various places of Saudi Arabia and reconstructed phylogeny for evaluation of genetic relationship among them. Internal transcribed spacer sequence of nrDNA (nrDNA-ITS) locus was used for the reconstruction of phylogeny among these species. Based on phylogenetic tree, Acacia etbaica and $A$. johnwoodii were close to each other. Similarly, A. ehrenbergiana and $A$. tortilis were close to each other. Thus, this gene locus was helpful in evaluating the genetic relationship among these species.
\end{abstract}

\section{Keywords}

nrDNA-ITS, Molecular Marker, Genomic DNA, PCR

\section{Introduction}

Trees and shrubs are important flora to maintain the ecosystem of any habitat where the vegetation is rich. The number of tree species in Saudi Arabia is more than the floristic element. Around $80 \%$ are found in the southwestern and western regions, including Taif region. Among the tree genera, Acacia contains the highest number of species followed by Ficus genus. Acacia genus (commonly known as wattle, thorntree or whistling thorn) (family: Fabaceae) contains around 1300 species and out of these, around 960 species are native to Australia. The remainder species are found from tropical to warm temperate region of both hemispheres. The plant of this genus is well nodulated under drought stress conditions.

Most of Acacia species grow in the arid and semi-arid regions of the world. Acacia species have social and economic importance throughout the warm and tropical regions of the world. These species withstand harsh climatic conditions and considered as the most successful trees in the arid regions [1] [2]. Xerophytic morpho- 
logical characteristics of Acacia species help to cope from harsh environmental conditions.

Different species of Acacia have been used for various purpose of human. Most of the Acacia produce tannins which is highly used in the leather industry [3]. Besides, Acacia species are also used as a forage, fuel, soil fertility and soil conservation. Many of them such as A. nilotica and A. polyacantha are used for local furniture for houses. Some species are used for medicinal purpose as $A$. nilotica pods are used for treating diarrhea, wounds, gums and kidney diseases [4].

Plant genetic diversity has important role in crop improvement for important desirable characteristic such as yield and quality traits. This genetic diversity can be preserve in plant genetic resources such as DNA library and GenBank and so forth. It can be used in breeding program for the development of potential cultivars for improving food production.

Number of molecular markers have been used for phylogenetic study such as random amplified polymorphic DNA (RAPD) [5], amplified fragment length polymorphism AFLP [6], restriction fragment length polymorphism (RFLP) etc. [7]. Molecular and biochemical researches have been performed on Australian and African Acacia species to provide useful markers for plant breeding and conservation programs [8]-[10].

These are polymorphic many molecular markers which have been used for genetic diversity study. DNA markers are more reproducible as compared to morphological and biochemical markers. Different chloroplast markers are also used for phylogenetic study as the size of these markers are short and easily amplifiable. The nuclear and chloroplast sequences have been used for the phylogenetic study of Acacia species. The gene dispersal by pollen as well as by seeds both have high impact on genetic diversity. The plants which are self-pollinated have narrow genetic diversity than the cross pollinated plant species

(http://www.crestonfoodaction.ca/site/preventing-cross-pollination-in-seed-plants/) [11]. The population of one species found at different places, have also genetic variations, as environmental factor create insertion or deletions in the genome.

Based on available literature about the Acacia species, in the current study, we used nrDNA-ITS locus for phylogenetic study of different species of Acacia species found in the Al-Baha province.

\section{Materials and Methods}

The study was done at Department of Biology, Al-Baha University, Saudi Arabia. The important Acacia species viz., Acacia etbaica, A. johnwoodii, A. ehrenbergiana and A. tortilis were collected from different places of AlBaha, Saudi Arabia. Genomic DNA was isolated from $200 \mathrm{mg}$ fresh leaves according to the modified DNeasy Plant Mini DNA isolation kit (Qiagen). The extracted genomic DNA was quantified and diluted in double distilled water for PCR reaction. Polymerase chain reaction (PCR) amplification was performed in a total volume of $25 \mu \mathrm{l}$. The reaction mix contained $40 \mathrm{ng}$ of temple DNA, $15 \mathrm{pmol} / \mathrm{l}$ of each forward/reverse ITS primer, 10 mmol/l Tris-Cl (pH 8.3), 0.5 U Taq DNA polymerase, 200 umol/l of each deoxyribonucleotide triphosphate, 50 $\mathrm{mmol} / \mathrm{l} \mathrm{KCl}$ and $25 \mathrm{mmol} / \mathrm{lMgCl} 2$. The PCR program consisted: $94^{\circ} \mathrm{C}$ for $3 \mathrm{~min} ; 94^{\circ}$ for $30 \mathrm{~s}$, annealing temperature $\left(54.3^{\circ} \mathrm{C}\right)$ for $30 \mathrm{~s}, 72^{\circ} \mathrm{C}$ for $1 \mathrm{~min}, 41$ cycles; $72^{\circ} \mathrm{C}$ for $10 \mathrm{~min}$. PCR product was electrophoresed on 1.2 percent agarose gel for confirmation of the amplified sequence. After amplification of the ITS loci, they were purified before sequencing.

Sequence generation, alignment and phylogeny reconstruction:

The nrDNA-ITS sequence was BLAST at GenBank database http://blast.ncbi.nlm.nih.gov/Blast.cgi for confirmation of our sequence. These sequences were processed further for phylogeny reconstruction using the MEGA 5 [12]. The sequence alignment was done using the ClustalX [13]. The branch support of phylogenetic tree was evaluated using 1000 bootstrap (BS) replicates with random sequence addition, equal weighting and TBR branch swapping, holding one tree at each replicate.

\section{Results and Discussion}

Acacia species were collected from different places of Al-Baha province, Saudi Arabia for their phylogenetic study (Figure 1). All Acacia species were identified by Taxonomist, at Department of Biology, Al-Baha University. The identified taxa were processed further for genomic DNA isolation. The extracted DNA was good in quality and yield as it was isolated using the Qiazen mini Kit.

Various species of Acacia have numerous medicinal values as mentioned above. These trees are also used by camels, sheep and goat as a fodder. These species play an important role in preservation and restoration of fertility 

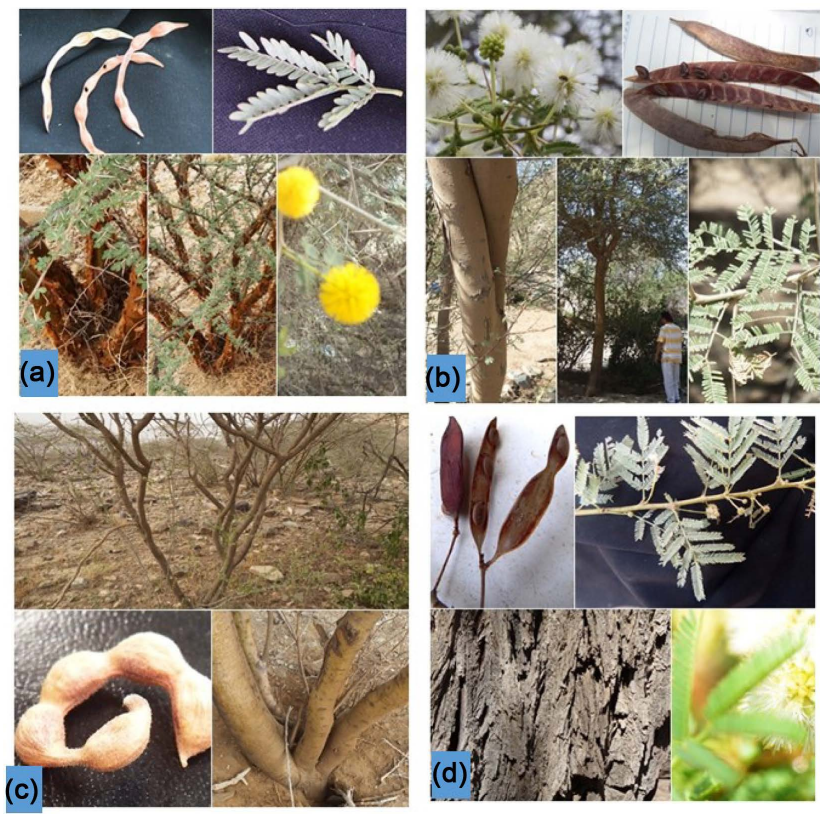

Figure 1. Acacia species collected from Al-Baha province of Saudi Arabia. (a) Acacia ehrenbergiana; (b) Acacia johnwoodii; (c) Acacia tortilis; (d) Acacia etbaica.

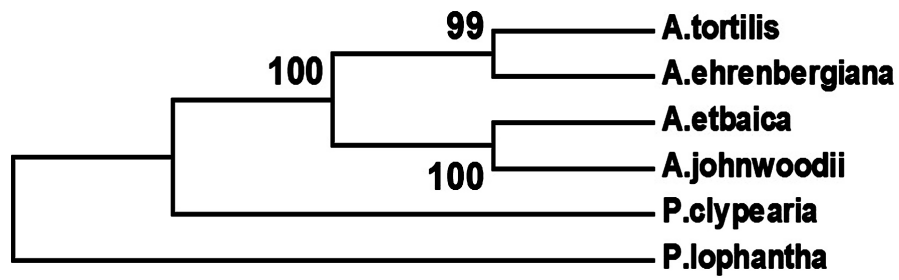

Figure 2. Phylogenetic tree was constructed using the Maximum Parsimony method. The percentage of replicate trees in which the associated taxa clustered together in the bootstrap test (1000 replicates) are shown next to the branches.

of poor and eroded soils. These legumes produce extensive, deep root system, in addition to their potential to fix atmospheric N2 [14]. In Tunisia, Acacia tortilis ssp. raddiana is the only wild and native Acacia, which grow spontaneously in arid and Saharan areas.

Different species are found in Saudi Arabia and some species have overlapping morphological characteristics. Therefore, their phylogenetic study is very necessary to know their relationship among them based on genetic markers. These markers are more informative than the non-sequencing based markers. We have collected different species of Acacia from various places of Al-Baha (Figure 1) for their phylogenetic study. Internal transcribed spacer sequence of nrDNA (nrDNA-ITS) was used for the phylogenetic study among the Acacia species. After amplification and sequencing of nrDNA-ITS loci, all sequences were BLAST at GenBank database for sequence similarity to the concerned genus/species. After confirmation of nrDNA-ITS, the phylogeny was reconstructed among these species for the evaluation of genetic similarity among them. The generated sequences of nrDNA-ITS have been submitted at GenBank database (accession number: KU168956, KU168957, KU168958). Paraserianthes lophantha and Pithecellobium clypearia were used as outgroup for the phylogenetic study of these Acacia species as shown at the base of phylogenetic tree. All species were clustered according to the sequence similarity (Figure 2).

The phylogenetic study of Acacia species also performed by other researchers using the molecular markers such as RAPD, ISSR and AFLP [15]-[18]. In our study, the obtained results of Acacia species was reproducible. However, this locus has been used for the phylogenetic study of many plant species such as Cypripedium, crocus, Eriobotrya etc. [19]-[21]. The use of this locus is very easy in phylogenetic study as its amplification and 
sequencing both are easy. Thus, nrDNA-ITS locus was useful marker in phylogenetic study of Acacia species growing in the Saudi Arabia. This marker is more useful in phylogenetic study as compared to the other polymorphic markers as described above.

\section{Acknowledgements}

We thank to Dr. Abdul Wali Al Khulaidi for providing good Pictures of Acacia species.

\section{References}

[1] Ibrahim, A.A.M. and Aref, I.M. (2000) Host Status of Thirteen Acacia Species to Meloidogyne jovanica. Journal of Nematology, 32, 609-613.

[2] Aref, I.M. (2000) Morphological Characteristics of Seeds and Seedling Growth of Some Native Acacia Trees in Saudi Arabia. Journal of King Saud University, Agricultural Sciences, 12, 31-95.

[3] Sahni, M. (1968) Important Trees of the Northern Sudan. Khartoum University Press, 40-63.

[4] Elkhalifa, K.F. (1996) Forest Botany. Khartoum University Press, 79-94.

[5] Williames, J.K., Kubelik, A., Livak, K., Rafalsky, J. and Tingey, S. (1990) DNA Polymorphisms Amplified by Arbitrary Primer and Useful as Genetic Markers. Nucleic Acids Research, 18, 6531-6535. http://dx.doi.org/10.1093/nar/18.22.6531

[6] Vos, R., Hogers, R., Bleeker, M., Reijans, M., Lee, T., Hornes, M., Frijters, A., Pot, J., Peleman, J. and Kuiper, M. (1995) AFLP: A New Technique for DNA Fingerprinting. Nucleic Acids Research, 23, 4407-4414. http://dx.doi.org/10.1093/nar/23.21.4407

[7] Beckman, J.S. and Soller, M. (1983) Restriction Fragment Length Polymorphisms in Genetic Improvement: Methodologies, Mapping and Costs. Theoretical and Applied Genetics, 67, 35-43. http://dx.doi.org/10.1007/BF00303919

[8] Butcher, P.A., Moran, G.F. and Perkins, H.D. (1998) RFLP Diversity in the Nuclear Genome of Acacia mangium. Heredit, 81, 205-213. http://dx.doi.org/10.1046/j.1365-2540.1998.00392.x

[9] McGranahan, M., Bell, J.C., Moran, G.F. and Slee, M. (1997) High Genetic Divergence between Geographic Regions in the Highly out Crossing Species Acacia aulacocarpa (Cunn. Ex Benth.). Forest Genetics, 4, 1-13.

[10] Playford, J., Bell, J.C. and Moran, G.F. (1993) A Major Disjunction in Genetic Diversity over the Geographic Range of Acacia Melanoxylon R. Australian Journal of Botany, 41, 355-368. http://dx.doi.org/10.1071/BT9930355

[11] Ashworth, S. (2002) Seed to Seed. 2nd Edition. Seed Savers Exchange, Decorah.

[12] Tamura, K., Peterson, D., Peterson, N., Stecher, G., Nei, M. and Kumar, S. (2011) MEGA5: Molecular Evolutionary Genetics Analysis Using Maximum Likelihood, Evolutionary Distance, and Maximum Parsimony Methods. Molecular Biology and Evolution, 28, 2731-2739. http://dx.doi.org/10.1093/molbev/msr121

[13] Thompson, J.D., Gibson, T.J., Plewniak, F., Jeanmougin, F. and Higgins, D.G. (1997) The Clustal X Windows Interface: Flexible Strategies for Multiple Sequence Alignment Aided by Quality Analysis Tools. Nucleic Acids Research, 24, 4876-4882. http://dx.doi.org/10.1093/nar/25.24.4876

[14] Nabli, M.A. (1989) Essai de Synthèse sur la Végétation et la Phyto-écologie Tunisienne. Faculté des Sciences, Tunis.

[15] Nanda, R.M., Nayak, S. and Rout, G.R. (2004) Studies on Genetic Relatedness of Acacia Tree Species Using RAPD Markers. Biologia, Bratislava, 59, 115-120.

[16] Widyatmoko, A.Y.P.B.C., Watanabe, A. and Shiraishi, S. (2010) Study on Genetic Variation and Relationships among Four Acacia Species Using RAPD and SSCP Marker. Journal of Forestry Research, 7, 125-143.

[17] Josiah, C.C., George, D.O., Eleazar, O.M. and Nyamu, W.F. (2008) Genetic Diversity in Kenyan Populations of Acacia senegal (L.) Willd revealed by Combined RAPD and ISSR Markers. African Journal of Biotechnology, 7, 23332340.

[18] Sirelkhatem, R. and Gaali, E.E.L. (2009) Phylogenic Analysis in Acacia senegal Using AFLP Molecular Markers across the Gum Arabic Belt in Sudan. African Journal of Biotechnology, 8, 4817-4823.

[19] Li, J.-H., Liu, Z.-J., Salazar, G.A., Bernhardt, P., Perner, H., Tomohisa, Y., Jin, X.-H., Chung, S.-W. and Luo, Y.-B. (2011) Molecular Phylogeny of Cypripedium (Orchidaceae: Cypripedioideae) Inferred from Multiple Nuclear and Chloroplast Regions. Molecular Phylogenetics and Evolution, 61, 308-320. http://dx.doi.org/10.1016/j.ympev.2011.06.006

[20] Harpke, D., Meng, S., Rutten, T., Kerndorff, H. and Blattner, F.R. (2012) Phylogeny of Crocus (Iridaceae) Based on One Chloroplast and Two Nuclear Loci: Ancient Hybridization and Chromosome Number Evolution. Molecular Phy- 
logenetics and Evolution, 66, 617-627. http://dx.doi.org/10.1016/j.ympev.2012.10.007

[21] Zhao, G.J., Yanga, Z.Q., Chen, X.P. and Guo, Y.H. (2011) Genetic Relationships among Loquat Cultivars and Some Wild Species of the Genus Eriobotrya Based on the Internal Transcribed Spacer (ITS) Sequences. Scientia Horticulturae, 130, 913-918. http://dx.doi.org/10.1016/j.scienta.2011.09.007 